\title{
Evidence for a strong correlation between season-dependent nitrate and potassium uptake in two deciduous trees
}

\author{
Mickaël Delaire · Jean-Claude Mauget • \\ François Beaujard
}

Received: 15 October 2013/Revised: 22 January 2014/ Accepted: 30 January 2014

(C) Springer-Verlag Berlin Heidelberg 2014

\begin{abstract}
Key message Nitrate and potassium uptake are strongly correlated in deciduous trees from bud break to leaf fall. A conceptual model for potassium cycling is proposed to explain this result.

Abstract We have studied the correlation between nitrate and potassium uptake in spring and autumn in two deciduous tree species: walnut and sycamore maple. Two-yearold trees were transplanted in early spring and cultivated on hydroponic recirculating nutrient solution systems in a greenhouse. Uptake of nitrate and potassium was surveyed daily during three consecutive weeks in mid-spring (i.e. during vegetative growth) and mid-autumn (i.e. during bud dormancy). Nitrate and potassium uptake was expressed per unit tree leaf area to account for tree size effect. Our results show that nitrate was much more absorbed than potassium in both species and its uptake remained nearly the same in spring and autumn. Contrary to this, potassium uptake was strongly reduced in autumn as a consequence of
\end{abstract}

Communicated by T. Koike.

M. Delaire $(\bowtie) \cdot$ J.-C. Mauget

AGROCAMPUS OUEST, UMR1345 IRHS, SFR4207

QUASAV, 49045 Angers, France

e-mail: mickael.delaire@agrocampus-ouest.fr

M. Delaire · J.-C. Mauget

INRA, UMR1345 IRHS, SFR4207 QUASAV,

49071 Beaucouzé, France

M. Delaire - J.-C. Mauget

Université d'Angers, UMR1345 IRHS, SFR4207 QUASAV,

49045 Angers, France

F. Beaujard

UMR547 PIAF, INRA-UBP, Site de Crouel,

63039 Clermont-Ferrand, France a strong reduction in vegetative growth. Although potassium uptake was strongly affected by seasonal variation in vegetative growth demand in both species, a positive and strong correlation between nitrate and potassium uptake was maintained in both species whatever the season. Essentially, any reduction in nitrate uptake as a consequence of decrease in nitrate availability in nutrient solution induced concomitantly a reduction in potassium uptake even if its concentration in the nutrient solution was sufficient to ensure potassium uptake. The results are discussed in the light of the accompanying role of potassium for nitrate uptake in plants. A conceptual scheme for internal/external potassium cycling in plant is proposed to explain the seasonal variations in nitrate and potassium uptake correlation in both deciduous tree species.

Keywords Hydroponic culture - Maple - Nitrate · Potassium $\cdot$ Uptake correlation $\cdot$ Walnut

\section{Introduction}

The two mineral elements mainly absorbed and used for plant growth demand are nitrogen $(\mathrm{N})$ and potassium (K) (Clarkson 1985; Marschner 1995; Shuman 2000). Nitrogen is a constituent of proteins, nucleic acids and many other small molecular species. It is available in the soil in a variety of forms including inorganic $\left(\mathrm{NO}_{3}{ }^{-}\right.$, $\mathrm{NH}_{4}{ }^{+}$and $\mathrm{NH}_{3}$ ) and organic nitrogen (amino acids and peptides), but nitrate $\left(\mathrm{NO}_{3}{ }^{-}\right)$derived from the $\mathrm{N}$-cycle constitutes the most important source of nitrogen for plants growing in aerobic soils (Crawford and Glass 1998; Nacry et al. 2013). Potassium is the most abundant and mobile cation in plant. It plays an important role in cell elongation, leaf movement, tropisms, metabolic 
homeostasis, osmoregulation, stomatal movement and wood formation in trees (Kochian and Lucas 1988; Maathuis et al. 1997; Fromm 2010). Potassium plays also a significant role in metabolites translocation between xylem and phloem fluxes known as xylem-phloemxylem recycling (Marschner et al. 1997).

In contrast to the well-known competition between ammonium and potassium uptake (Marschner 1995), several studies, especially on herbaceous species, have shown a strong and positive interaction between nitrate and potassium to ensure plant growth demand (reviewed in Zhang et al. 2010). Actually, potassium is known to be the major accompanying cation for nitrate uptake (Ivashikina and Feyziev 1998) and translocation toward shoots through the xylem vessels (Blevins et al. 1978; Minotti et al. 1968) and it promotes nitrate reductase activity in leaves (Wakhloo and Staudt 1988). Furthermore, potassium long-distance recirculation from shoots to roots together with organic acids such as malate provides a source of $\mathrm{HCO}_{3}{ }^{-}$in roots involved in $\mathrm{NO}_{3}{ }^{-}$uptake regulation (Ben Zioni et al. 1970; Casadesus et al. 1995; Touraine et al. 1988). These mechanisms determine internal cycling of potassium between roots and shoots that is well described for growing herbaceous (Jiang et al. 2001; Lu et al. 2005) and woody plants (Proe et al. 2000; Weatherall et al. 2006). Such a cycling could be very important since Engels and Kirkby (2001) have estimated that $21-51 \%$ of the potassium translocated from roots to shoots in maize is not directly derived from root uptake but from cycling.

All this evidence suggests, therefore, a strong correlation between nitrate and potassium uptake to ensure plant growth demand as generally described in literature (Marschner 1995). However, little is known about the maintenance of this uptake correlation when plant growth demand is strongly reduced. To our knowledge, this question has never been investigated in annual herbaceous species because nitrate and to a greater extent potassium uptake are always considered largely dependent on plant growth demand. However, woody species are known to absorb and then store significant amounts of nitrate in autumn (Millard 1996) without any strong plant growth demand. Therefore, this question needs to be investigated because it could imply a particular interaction between nitrate and potassium uptake systems.

In this context, the objective of the present work was to study and compare $\mathrm{NO}_{3}{ }^{-}$and $\mathrm{K}^{+}$uptake correlation in deciduous trees in spring and autumn. The study was conducted with two deciduous trees to better generalize the obtained results. Young walnut (Juglans regia $\times J$. major, L.) and sycamore maple trees (Acer pseudoplatanus, L.) were chosen based first because of their capacity to store important amounts of nitrogen (Millard and Proe 1991; Weinbaum and Kessel 1998) and second because of their contrasting root architectures (i.e. fascicular for maple, versus a strong carbon-rich tap root for young walnut trees) which could induce some differences in nitrate and potassium active uptake capacity in autumn.

\section{Materials and methods}

\section{Study periods}

For experimental reasons, studies with walnut and maple trees were conducted separately during two different years, in 2000 and 2001. Nitrate and potassium uptake correlations were studied in spring and in autumn during three consecutive weeks. In spring, the study was conducted nearly 1 month after spring bud burst of young walnut and maple trees (occurring in early April in both species) to reduce the effect of some initial physiological process (i.e. root system regeneration, N-remobilization) which could interact with nutrient uptake dynamics. In autumn, the study was conducted during bud dormancy in October at the beginning of leaf senescence. Growth of tree leaf area was measured for both species throughout the growing period to account for tree size effect.

\section{Plant material and growth conditions}

In early spring, eighteen 2-year-old walnut trees seedlings (Juglans nigra $\times$ Juglans major; height: $0.44 \pm 0.08 \mathrm{~m}$; trunk basal diameter: $16.7 \pm 2.0 \mathrm{~mm}$ ) and twelve 2-yearold maple tree cuttings (Acer pseudoplatanus; height: $1.15 \pm 0.10 \mathrm{~m}$; trunk basal diameter : $16.3 \pm 1.0 \mathrm{~mm}$ ), were transplanted (fine roots pruned and root system washed) and grown in individual cylindrical containers (diameter $\times$ height $=0.20 \times 0.30 \mathrm{~m})$ filled with perlite as substrate (particle diameter range $2-5 \mathrm{~mm}$ ) and covered with a 1-cm-thick layer of waterproof silex (diameter 2-3 $\mathrm{mm}$ ) to limit evaporation and the development of algae. Transplanted specimens of walnut and maple were distributed, respectively, over six and four hydroponic recirculating nutrient solution systems (i.e. three trees per system; Fig. 1), in a greenhouse $\left(15 \pm 2{ }^{\circ} \mathrm{C}\right.$ at night; $24 \pm 2{ }^{\circ} \mathrm{C}$ at day; no supplemental lighting).

During the entire growing period (i.e. from early spring to the end of summer), each set of three plants was dripirrigated with 701 of nutrient solution, which was recirculated for $1 \mathrm{~h}$ six times per day. The only source of nitrogen was nitrate to (1) study specifically the correlation between nitrate and potassium uptake and to avoid any competition between potassium and ammonium uptake and (2) because maple and walnut are rather calcicolous species which prefer nitrate as source of nitrogen. The nutrient solution had a $\mathrm{pH}$ of 5.5 and comprised (initial concentrations) $\left(\mathrm{mmol} \mathrm{l}{ }^{-1}\right) 1.69 \mathrm{NO}_{3}{ }^{-} ; 0.17 \mathrm{P} ; 0.97 \mathrm{~K}^{+} ; 0.39 \mathrm{Ca}^{2+} ; 0.35$ 
Fig. 1 Schematic

representation of a hydroponic

recirculating nutrient system. 1 , 2, 3 mixing, watering and recovering pumps, respectively. The arrows indicate the flow direction of the nutrient solution

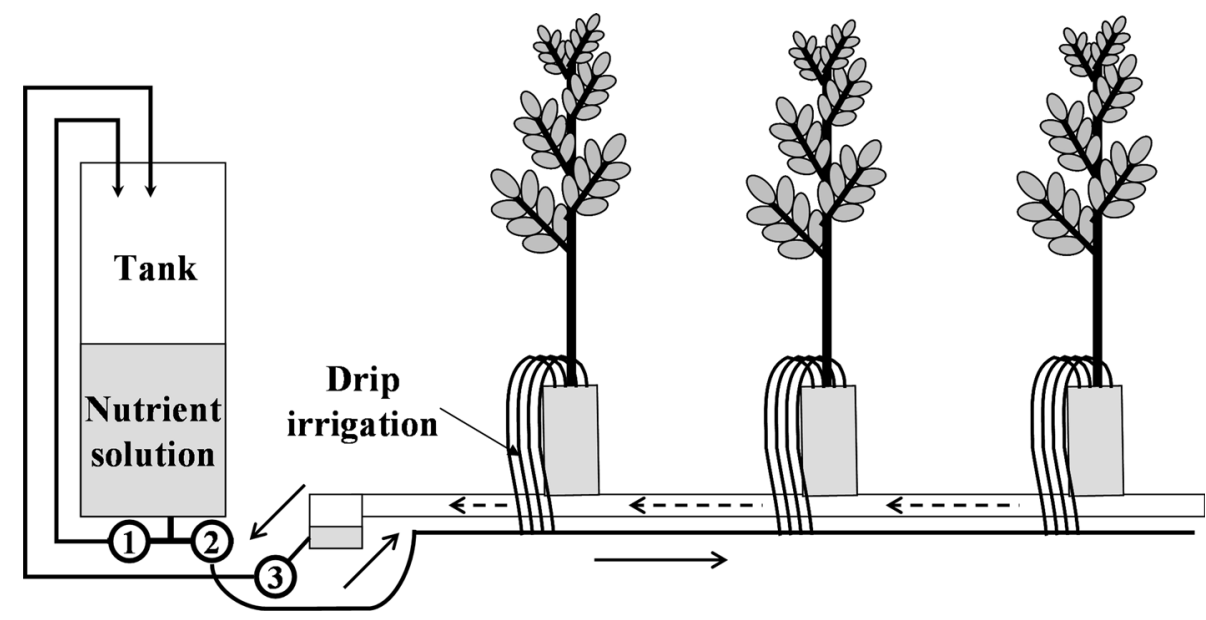

$\mathrm{Mg}^{2+} ; 0.24 \mathrm{SO}_{4}{ }^{2-} ;$ and micronutrients-Kanieltra ${ }^{\circledR}-$ $\left(\mu \mathrm{mol} \mathrm{l}{ }^{-1}\right)$ : $20.6 \mathrm{~B}$; $0.65 \mathrm{Cu} ; 10.7 \mathrm{Fe}$; $11.6 \mathrm{Mn}$; $0.28 \mathrm{Mo}$; and $3.2 \mathrm{Zn}$. The nutrient solution was exchanged with fresh solution every week to ensure a sufficient nutrient availability to maintain vegetative growth.

At the end of summer, four walnut and six maple trees were selected according to similar morphological parameters (i.e. height, tree leaf area and trunk basal diameter) for a follow-up experiment conducted in autumn. The selected specimens of both species were redistributed over two different hydroponic cultural systems and cultivated under the same conditions previously described.

Tree leaf area

Leaf area per tree was surveyed to express nitrate and potassium uptake per unit of leaf area to account for the tree size effect. Leaf area was measured with a non destructive method based on two different allometric relationships:

Walnut tree leaf area $=n \cdot K_{1} \cdot L_{\mathrm{w}} \cdot\left(L_{\mathrm{tl}}+L_{1}\right)$ with $K_{1}$

$$
=0.025 ; R^{2}=0.97 ; \quad P<0.001
$$

Maple tree leaf area $=K_{2} \cdot L_{\mathrm{w}} \cdot L_{1}$ with $K_{2}$

$$
=0.74 ; R^{2}=0.94 ; \quad P<0.001 .
$$

where $L_{\mathrm{w}}$ and $L_{\mathrm{l}}$ are leaf width and length (m); $n$ is number of leaflets; $L_{\mathrm{tl}}$ is terminal leaflet length (m); and $K_{1}$ and $K_{2}$ are constants, (form factors). As a control, tree leaf area $\left(\mathrm{m}^{2}\right)$ was measured with a leaf area meter (Model Mk2 Delta-T Area Measurement System, Delta-T Devices, Cambridge, U.K.). For each species, the equation parameters were validated five times in spring using leaf areas measured with the leaf area meter as an index. During the spring growth period, leaf area was surveyed daily for six walnut and maple trees, respectively. Those measurements were then computed as linear Eq. (3) to estimate temporal variations in leaf area $\left(\mathrm{TLA}_{\mathrm{t}}\right)$ for each tree during the 3 weeks' study period in spring:

$\mathrm{TLA}=A t+B$.

where $A$ and $B$ are species-dependent parameters and $t$ is time in Julian days.

In autumn, tree leaf areas were estimated a single time for each tree with the allometric relationships (Eqs. 1 and 2).

Survey of $\mathrm{NO}_{3}{ }^{-}$and $\mathrm{K}^{+}$uptake

Nitrate and potassium uptake was computed from the temporal variations in the quantity of each element in the nutrient solution pool (Beaujard and Hunault 1997). We sampled 0.1251 of nutrient solution and measured tank volume after each watering event (i.e. every $4 \mathrm{~h}$ ) to estimate the quantity of $\mathrm{NO}_{3}^{-}$and $\mathrm{K}^{+}$remaining in the solution. Nitrate concentration was measured with a continuous flow spectro-colorimeter (Model Evolution II, Alliance Instruments, Cergy-Pontoise, France) and $\mathrm{K}^{+}$ concentration was determined with an atomic absorption spectrophotometer (Model SpectrA A-10, Varian, Les Ulis, France).

The mathematical model used to compute daily $\mathrm{NO}_{3}{ }^{-}$ and $\mathrm{K}^{+}$uptake, previously described in Beaujard and Hunault (1997), Delaire et al. (2005) and Thitithanakul et al. (2013), considers time, concentration (sampling) and volume discontinuities, remaining water in the substrate (estimated stable) and the number of plants.

Data analysis

In both species nitrate and potassium uptake was surveyed during a period of three consecutive weeks in spring 


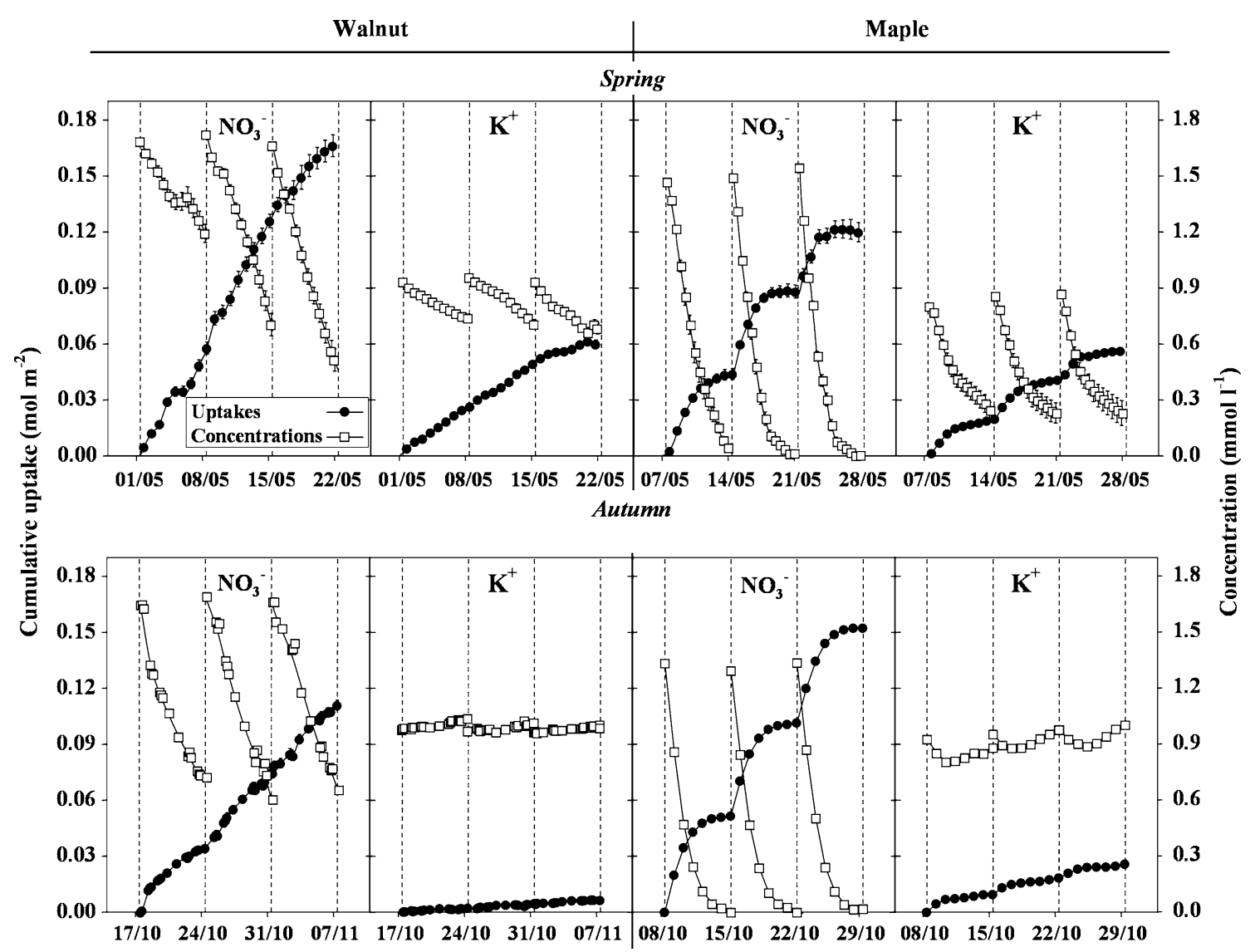

Fig. 2 Temporal variations in nitrate and potassium uptake expressed per unit tree leaf area $\left(\mathrm{mol} \mathrm{m}^{-2}\right.$, filled circle and concentration ( $\mathrm{mmol} \mathrm{l} \mathrm{l}^{-1}$, open square) during the 3 -week periods in spring and autumn in walnut and maple trees. Bars are standard errors (in spring:

( 2 months after bud burst) and in autumn (during bud dormancy). In spring and autumn, variations in the uptake of the two elements were calculated for each species as mean values expressed per unit tree leaf area obtained for each tree. Linear regression analysis using the $\mathrm{R}$ package (R Development Core Team, 2008) was used to analyze the correlation between nitrate and potassium uptake in spring and autumn. For each linear regression analysis $(y=a x+b)$, where $y$ is nitrate uptake, $x$ is potassium uptake, and $a$ the correlation coefficient, the value for $b$ (the offset) was generally not significant. The correlation factor $a$ was considered significant when $P$ was $<0.05$.

\section{Results}

Nitrate and potassium uptake

Independent of season and species, nitrate and potassium uptake dynamics depended largely on the availability (i.e. concentrations) of both elements in the nutrient solution $n=18$ and 12 for walnut and maple, respectively; in autumn: $n=6$ and 4 for walnut and maple, respectively). The dashed lines indicate the days on which the nutrient solution was renewed

(Fig. 2). At the moment of nutrient solution renewal, nitrate and potassium concentrations were very high (1.7 and $0.1 \mathrm{~mol} \mathrm{l}^{-1}$, respectively) to ensure a strong uptake. Progressively, both elements concentrations decreased as a consequence of plant absorption up to shortly before the nutrient solution was renewed (Fig. 2). In maple, nitrate and potassium concentrations decreased to an extent that plants could not absorb any more of these nutrients already a few days before the renewal of the nutrient solution. Such limiting conditions, which were observed throughout the entire study period in spring and autumn, induced a kind of "step-by-step" uptake dynamics for both elements (Fig. 2). Contrary to this, the concentrations of both elements were still very high (always more than $0.5 \mathrm{~mol} \mathrm{l}^{-1}$ ) in walnut and, therefore, led to constant uptake rates, illustrated by the relatively linear uptake of both elements in spring and autumn.

Although nitrate and potassium uptake dynamics were different with respect to species, the absorption of nitrate was much greater. At the end of the spring study period, its cumulative uptake reached 0.16 and $0.12 \mathrm{~mol} \mathrm{~m}^{-2}$ in 


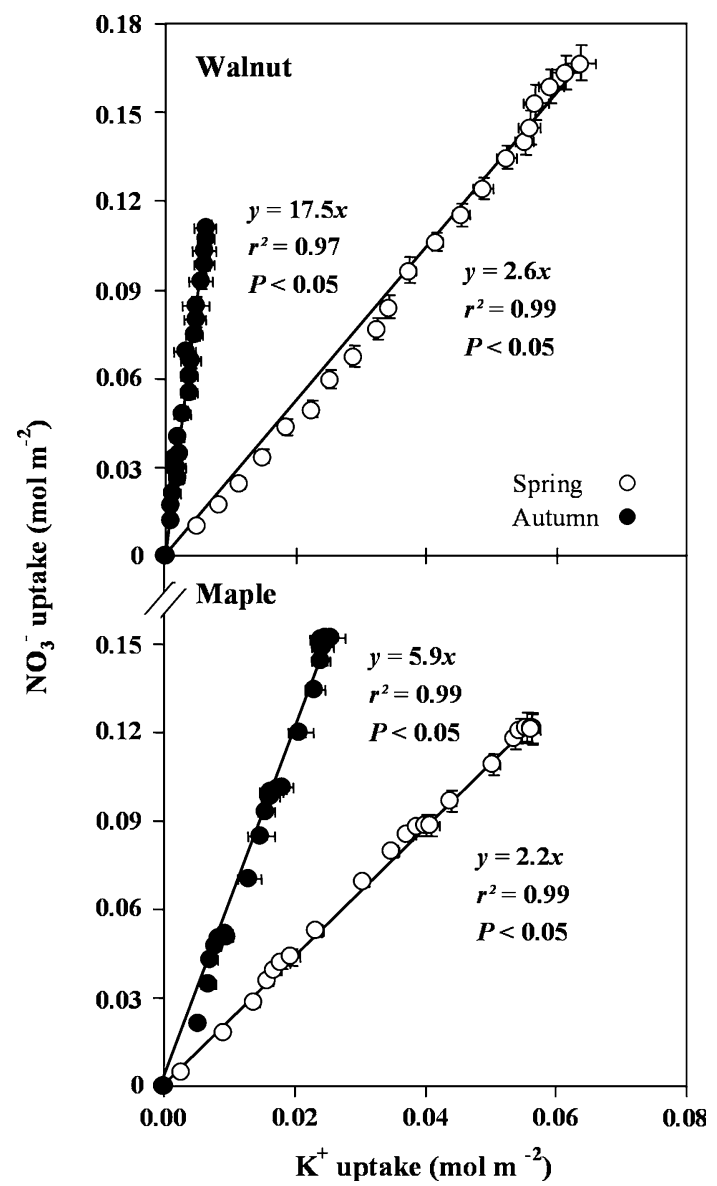

Fig. 3 Nitrate uptake $\left(\mathrm{mol} \mathrm{m}^{-2}\right)$ as a function of potassium uptake $\left(\mathrm{mol} \mathrm{m}{ }^{-2}\right)$ during the 3 -week periods in spring and autumn. Each point represents the mean in nitrate and potassium uptakes and bars are standard errors (in spring: $n=18$ and 12 for walnut and maple, respectively; in autumn: $n=6$ and 4 for walnut and maple, respectively). Lines represent the linear regression

walnut and maple, respectively, against only $0.06 \mathrm{~mol} \mathrm{~m}^{-2}$ in potassium (Fig. 2). In autumn, nitrate uptake was still very high in both species (more than $0.1 \mathrm{~mol} \mathrm{~m}^{-2}$ ), whereas potassium uptake was strongly reduced $\left(<0.03 \mathrm{~mol} \mathrm{~m}^{-2}\right)$.

Correlation between nitrate and potassium uptake

In both species, nitrate and potassium uptake were strongly and significantly correlated during the study periods in spring and in autumn (Fig. 3). The ratio between nitrate and potassium uptake reached 2.2 and 2.6 in spring for walnut and maple, respectively. It increased strongly in autumn to reach, respectively, 17.5 and 5.9 as a consequence of a strong decrease in potassium uptake. The decrease was much more pronounced in walnut (Fig. 3).

Such a correlation defined at a temporal scale of three consecutive weeks could also be observed at a weekly scale in maple tree. As we have seen before, nitrate uptake decreased strongly a few days before the renewal of the nutrient solution as a consequence of a precocious depletion situation. At the same time, potassium uptake decreased strongly even when its concentration was still sufficient to ensure uptake in spring (more than $0.2 \mathrm{~mol} \mathrm{l}^{-1}$ ) and more particularly in autumn (more than $0.9 \mathrm{~mol} \mathrm{l}^{-1}$ ) (Fig. 2). In autumn, we could even notice a weak increase in potassium concentration in the nutrient solution concomitantly with the strong reduction in nitrate uptake.

\section{Discussion}

Correlation between nitrate and potassium uptake

As had already been shown in herbaceous species (Ivashikina and Feyziev 1998; Rufty et al. 1981), nitrate and potassium uptake in spring is also strongly correlated in woody species such as walnut and maple. It has often been reported that this correlation could be mediated by plant growth demand which requires a large ratio between nitrogen (i.e. nitrate in our study) and potassium supply (Clarkson 1985; Shuman 2000; Zhang et al. 2010). Furthermore, the ratio between nitrate and potassium uptake measured here (around 2) is in accordance with the $\mathrm{N} / \mathrm{K}$ ratio generally observed in woody species (Marschner 1995) and specifically in maple and walnut (unpublished data). The most surprising result is that this correlation seems to be maintained in autumn when vegetative growth was already strongly reduced during this same period.

Furthermore, although young walnut and maple trees differ strongly in their capacity to store carbon in their root system (i.e. carbon-rich tap root system in walnut tree), our result exhibited no difference in nitrate uptake capacity especially in autumn where remobilised carbon used for active uptake contributes to reduce total carbon storage in the root system (Cheng et al. 2004). However, as described in the literature (reviewed in Millard and Grelet 2010), available stored carbon in the root system is not a limiting factor in woody species. Thus, a high level of nitrate uptake in walnut and maple, together with $\mathrm{N}$ remobilized from senescent leaves often observed in deciduous trees in autumn (Millard 1996), could play a decisive role for $\mathrm{N}$ storage. Contrary to this, potassium uptake decreased strongly during the same period and, therefore, seems to be much more related to plant growth demand. The maintenance of a strong correlation between the uptake of both elements could, therefore, be explained by the positive effect of potassium for nitrate uptake through the root plasma membrane (Ivashikina and Feyziev 1998). However, this raises the question how to explain the strong 
Fig. 4 Conceptual model to explain variations in nitrate and potassium uptake correlation in spring and autumn: nitrate and potassium influx are hypothesized to be strongly correlated throughout all seasons. Thickness of lines indicates the relative strength of flow from low (dashed line) to very high (thick solid line). Oval symbols at the root system indicate the transporter system with active influx system for nitrate (in black) and potassium (in grey) and efflux system (in white). The arrows under each scheme indicate the relative importance of nitrate and potassium net uptake in spring and in autumn. See text for further explanations

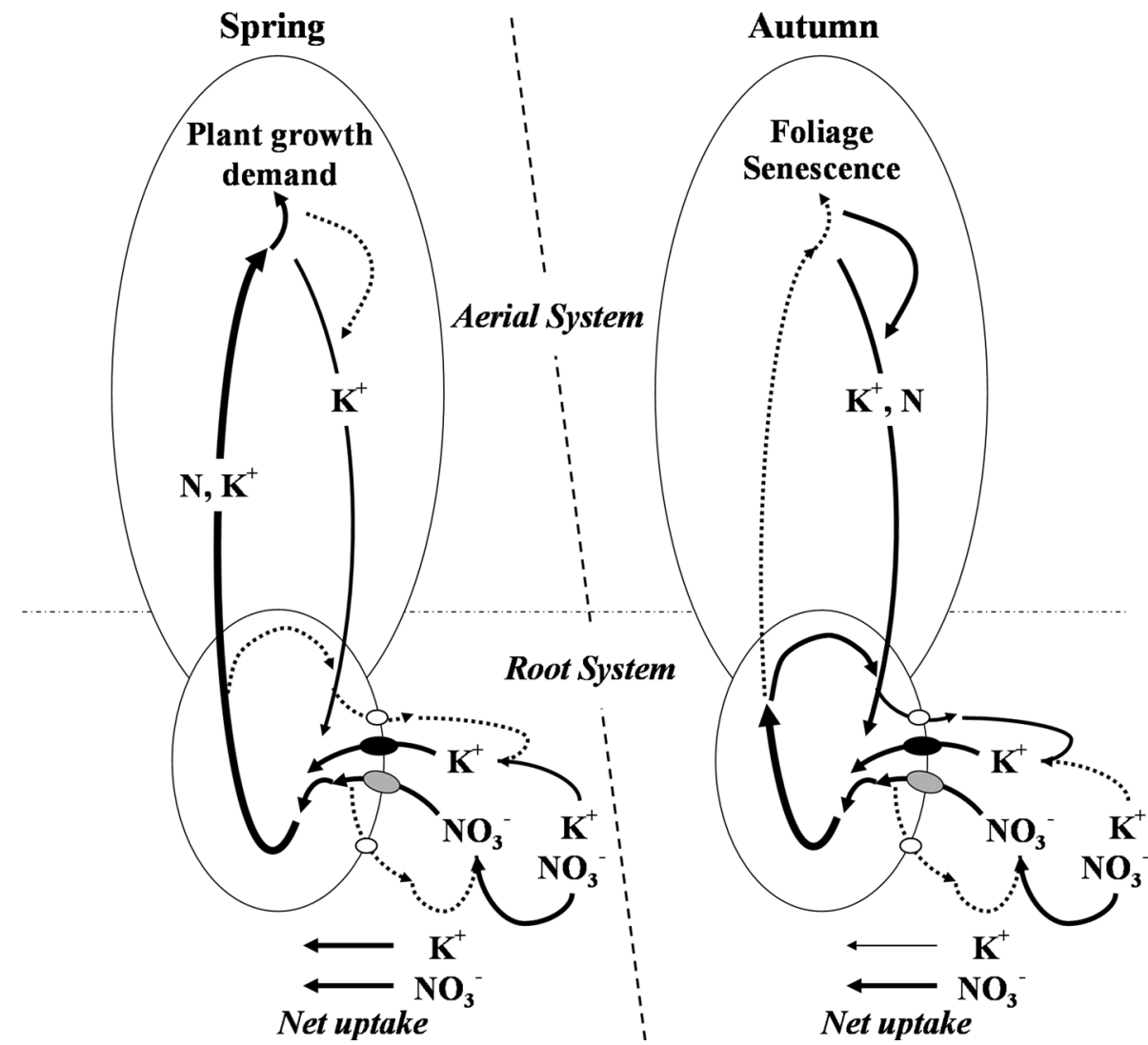

divergence in the $\mathrm{NO}_{3}{ }^{-} / \mathrm{K}^{+}$uptake ratio between spring and autumn.

\section{Conceptual and explicative model}

We have developed a conceptual and explicative model to explain the variation in $\mathrm{NO}_{3}{ }^{-} / \mathrm{K}^{+}$uptake ratio (Fig. 4). As with all mineral elements, nitrate and potassium uptake corresponds to a mass balance between influx and efflux. The influx of both elements is an active process ensured by different transporter systems well documented in literature (Forde 2000; Schachtman 2000; Tsay et al. 2007; Szczerba et al. 2009). In contrast, the mechanisms of nitrate and potassium efflux are still largely unknown but are often considered under low-mineral conditions induced by a concentration gradient and mediated by trans-membrane proteins (Aslam et al. 1996; Grouzis et al. 1997; Schachtman 2000; Szczerba et al. 2006). Although Ivashikina and Feyziev (1998) have suggested that potassium availability could modulate nitrate efflux rather than nitrate influx, the precise interaction between nitrate and potassium influx and efflux is still unknown. However, we can speculate that nitrate and potassium influx are strongly correlated to maintain an electroneutrality at each side of the membrane as has been frequently described for mineral uptake (Marschner 1995).
In spring, plant growth demand induced a strong nitrate and potassium influx. At the same time, potassium longdistance internal cycling along with local xylem-phloemxylem cycling, very strong under conditions of vigorous vegetative growth as shown in herbaceous (Engels and Kirkby 2001) and woody species (Weatherall et al. 2006), could allow for considerable allocation of nitrogen from roots to leaves (Fig. 4). In this context, potassium and nitrate efflux from the root system could be considered very low compared to their influx.

In autumn, remobilization of nitrogen in the form of amino acids from leaves to perennial organs, well described in deciduous trees (Millard 1996; Millard and Grelet 2010), could be associated with co-transportation by potassium as observed in herbaceous species (Ben Zioni et al. 1971; Jeschke et al. 1985). Such a remobilisation could alter the internal potassium cycling process into an unidirectional flux from leaves to roots which in turn could strongly increase potassium concentrations in the root system and induce, therefore, a feedback regulation of potassium net uptake as described by White (1997) in rye and observed for walnut and maple (this study).

However, according to the hypothesis exposed above, potassium influx must be maintained to ensure nitrate influx. In this case, a decrease in potassium net uptake could be induced by an increase in potassium efflux. Such interaction 
could induce, therefore, local internal/external cycling of potassium which seemed to depend upon nitrate net uptake. Actually, as observed in our study for maple tree a few days before the nutrient solution renewal, any reduction in nitrate uptake induced an increase in potassium concentration in the root environment as a consequence of decrease in potassium influx and probably an increase in its efflux as demonstrated by Pettersson (1984) in sunflower under low nitrate conditions. The different ratio $\mathrm{NO}_{3}{ }^{-} / \mathrm{K}^{+}$between walnut and maple (i.e. 17.5 and 5.9, respectively) in autumn could be, therefore, assigned to a stronger potassium efflux in walnut maybe due to a advanced senescence of leaf (personal observation) compared to maple.

However, one question still remains unanswered: can nitrate uptake possibly take place under conditions of $\mathrm{K}^{+}$ deprivation in autumn? Results obtained in herbaceous plants have demonstrated that potassium availability could strongly modulate nitrate uptake and nitrate use efficiency in crops (Zhang et al. 2010). However, in the present study (woody species in autumn), we can speculate that potassium efflux related to an increase in potassium concentration within the root system could always be sufficiently high to ensure a local cycling of potassium to ensure nitrate uptake. Given the present experimental evidence, this reasoning remains in the realm of speculation and needs to be validated with further experiments conducted under conditions of $\mathrm{K}^{+}$-deprivation. In any case, our results in walnut and maple suggest an important interaction between nitrate and potassium transporter systems at the root level which needs to be investigated as suggested by Tsay et al. (2011) in herbaceous species and more precisely the possible role of kinase implicated in nitrate and potassium high affinity transporter systems.

\section{Conclusion}

Although we have chosen contrasting woody species based on their root system susceptible to induce differences in nitrate uptake capacity in autumn, both species are able to absorb strongly nitrate and weakly potassium in autumn. Nitrate uptake in autumn has been associated with increase in root pressure in walnut (Ewers et al. 2001) and in maple tree (unpublished data). Base on this observation, it could be interesting to validate the proposed conceptual scheme in woody species known to never develop strong root pressure in autumn (and maybe also strong nitrate uptake) such as oak (Cruiziat et al. 2002).

Acknowledgments Financial support was provided by the National Institute of Agronomy Research, INRA (Department of Environment and Agronomy). We are very grateful to Dr. P. Raimbault (former Assistant Professor at the National Institute of Horticulture, INH) for providing maple tree clones. We also thank M. Sigogne, O. Douillet and N. Masson for their technical assistance. Last, thanks go to Dr. G. Buck-Sorlin and Dr. T. Améglio for useful comments on the manuscript.

Conflict of interest The authors declare that they have no conflict of interest.

\section{References}

Aslam M, Travis RL, Rains DW (1996) Evidence for substrate induction of a nitrate efflux system in barley roots. Plant Physiol 112:1167-1175

Beaujard F, Hunault G (1997) An original approach to study the kinetics of mineral element uptake for some woody species. Acta Hortic 435:243-253

Ben Zioni A, Vaadia B, Lips SH (1970) Correlation between nitrate reduction, protein synthesis and malate accumulation. Physiol Plant 23:1039-1047

Ben Zioni A, Vaadia B, Lips SH (1971) Nitrate uptake by roots as regulated by nitrate reduction products of shoot. Physiol Plant 24:288-290

Blevins DG, Hiatt AJ, Lowe RH, Leggett JE (1978) Influence of K on the uptake, translocation and reduction of nitrate by barley seedlings. Agron J 70:393-396

Casadesus J, Tapia L, Lambers $\mathrm{H}$ (1995) Regulation of $\mathrm{K}^{+}$and $\mathrm{NO}_{3}{ }^{-}$ fluxes in roots of sunflower (Helianthus annuus) after changes in light intensity. Physiol Plant 93:279-285

Cheng L, Ma FW, Ranwala D (2004) Nitrogen storage and its interaction with carbohydrates of young apple trees in response to nitrogen supply. Tree Physiol 24:91-98

Clarkson DT (1985) Factors affecting mineral acquisition by plants. Annu Rev Plant Physiol 36:77-115

Crawford NM, Glass ADM (1998) Molecular and physiological aspects of nitrate uptake in plants. Trends Plant Sci 3:389-395

Cruiziat P, Cochard H, Améglio T (2002) Hydraulic architecture of trees: main concepts and results. Ann For Sci 59:723-752

Delaire M, Frak E, Sigogne M, Adam B, Beaujard F, Le Roux X (2005) Sudden increase in atmospheric $\mathrm{CO}_{2}$ concentration reveals strong coupling between shoot carbon uptake and root nutrient uptake in young walnut trees. Tree Physiol 25:229-235

Engels C, Kirkby EA (2001) Cycling of nitrogen and potassium between shoot and roots in maize as affected by shoot and root growth. J Plant Nutr Soil Sci 164:183-191

Ewers FW, Améglio T, Cochard H, Beaujard F, Martignac M, Vandame M, Bodet C, Cruiziat P (2001) Seasonal variation in xylem pressure of walnut trees: root and stem pressures. Tree Physiol 21:1123-1132

Forde BG (2000) Nitrate transporters in plants: structure, function and regulation. Biochim Biophys Acta Biomembr 1465:219-235

Fromm J (2010) Wood formation of trees in relation to potassium and calcium nutrition. Tree Physiol 30:1140-1147

Grouzis JP, Pouliquin P, Rigaud J, Grignon C, Gibrat R (1997) In vitro study of passive nitrate transport by native and reconstituted plasma membrane vesicles from corn root cells. Biochim Biophys Acta Biomembr 1325:329-342

Ivashikina NV, Feyziev YM (1998) Regulation of nitrate uptake in maize seedlings by accompanying cations. Plant Sci 131:25-34

Jeschke WD, Atkins CA, Pate JS (1985) Ion circulation via phloem and xylem between root and shoot of nodulated white lupin. J Plant Physiol 117:319-330

Jiang F, Li C, Jeschke WD, Zhang F (2001) Effect of top excision and replacement by 1 -naphthylacetic acid on partition and flow of potassium in tobacco plants. J Exp Bot 52:2143-2150 
Kochian LV, Lucas WJ (1988) Potassium transport in roots. Ad Bot Res 15:93-178

Lu YX, Li CJ, Zhang FS (2005) Transpiration, potassium uptake and flow in tobacco as affected by nitrogen forms and nutrient levels. Ann Bot 95:991-998

Maathuis FJM, Sanders D, Gradmann D (1997) Kinetics of highaffinity $\mathrm{K}^{+}$uptake in plants, derived from $\mathrm{K}^{+}$-induced changes in current-voltage relationships. Planta 203:229-236

Marschner H (1995) Mineral nutrition of higher plants, 2nd edn. Academic Press, London

Marschner H, Kirkby EA, Engels C (1997) Importance of cycling and recycling of mineral nutrients within plants for growth and development. Bot Acta 110:265-273

Millard P (1996) Ecophysiology of the internal cycling of nitrogen for tree growth. Z Pflanzenernähr Bodenk 159:1-10

Millard P, Grelet GA (2010) Nitrogen storage and remobilization by trees: ecophysiological relevance in a changing world. Tree Physiol 30:1083-1095

Millard P, Proe MF (1991) Leaf demography and the seasonal internal cycling of nitrogen in sycamore (Acer pseudoplatanus L.) seedlings in relation to nitrogen supply. New Phytol 117:587-596

Minotti PL, Williams DC, Jackson WA (1968) Nitrate uptake and reduction as affected by calcium and potassium. Soil Sci Soc Am Proc 32:692-702

Nacry P, Bouguyon E, Gojon A (2013) Nitrogen acquisition by roots: physiological and developmental mechanisms ensuring plant adaptation to fluctuating resource. Plant Soil 370:1-29

Pettersson S (1984) Effects of nitrate on influx, efflux and translocation of potassium in young sunflower plants. Physiol Plant 61:663-669

Proe MF, Midwood AJ, Craig J (2000) Use of stable isotopes to quantify nitrogen, potassium and magnesium dynamics in young Scots pine (Pinus sylvestris). New Phytol 146:461-469

Rufty TW, Jackson WA, Raper CD (1981) Nitrate reduction in roots as affected by the presence of potassium and by flux of nitrate through the roots. Plant Physiol 68:605-609

Schachtman DP (2000) Molecular insights into the structure and function of plant $\mathrm{K}^{+}$transport mechanisms. Biochim Biophys Acta Biomembr 1465:127-139
Shuman LM (2000) Mineral nutrition. In: Wilkinson RE (ed) Plantenvironment interactions. Marcel Dekker Inc, New York, pp 65-109

Szczerba MW, Britto DT, Kronzucker HJ (2006) Rapid, futile $\mathrm{K}^{+}$ cycling and pool-size dynamics define low-affinity potassium transport in barley. Plant Physiol 141:1494-1507

Szczerba MW, Britto DT, Kronzucker HJ (2009) $\mathrm{K}^{+}$transport in plants: physiology and molecular biology. J Plant Physiol 166:447-466

Thitithanakul S, Pétel G, Chalot M, Beaujard F (2013) Supplying nitrate before bud break induces pronounced changes in $\mathrm{N}$ nutrition and growth of young poplars. Funct Plant Biol 39:795-803

Touraine B, Grignon N, Grignon C (1988) Charge balance in $\mathrm{NO}^{-}$fed soybean. Estimation of $\mathrm{K}^{+}$and carboxylate recirculation. Plant Physiol 88:605-612

Tsay YF, Chiu CC, Tsai CB, Ho CH, Hsu PK (2007) Nitrate transporters and peptides transporters. FEB Lett 581:2290-2300

Tsay YF, Ho CH, Chen HY, Lin SH (2011) Integration of nitrogen and potassium signaling. Ann Rev Plant Biol 62:207-226

Wakhloo JL, Staudt A (1988) Development of nitrate reductaseactivity in expanding leaves of Nicotiana tabacum in relation to the concentration of nitrate and potassium. Plant Physiol $87: 258-263$

Weatherall A, Proe MF, Craig J, Cameron AD, Midwood AJ (2006) Internal cycling of nitrogen, potassium and magnesium in young Sitka spruce. Tree Physiol 26:673-680

Weinbaum S, Kessel CV (1998) Quantitative estimates of uptake and internal cycling of ${ }^{14} \mathrm{~N}$-labeled fertilizer in mature walnut trees. Tree Physiol 18:795-801

White PJ (1997) The regulation of $\mathrm{K}^{+}$influx into roots of rye (Secale cereale $\mathrm{L}$.) seedlings by negative feedback via the $\mathrm{K}^{+}$flux from shoot to root in the phloem. J Exp Bot 48:2063-2073

Zhang F, Niu J, Zhang W, Chen X, Li C, Yuan L, Xie J (2010) Potassium nutrition of crops under varied regimes of nitrogen supply. Plant Soil 335:21-34 